\title{
Cover Crop/Dairy Manure Management Systems: WATER Quality and SoIL System IMPacts
}

\author{
J. D. Kern, M. L. Wolfe
}

\begin{abstract}
A field study was conducted to determine impacts of corn silage production systems that included a rye cover crop and application of liquid dairy manure in the spring and fall on water quality and soil characteristics. Four management systems were each replicated four times: traditional, double-crop, roll-down, and undercut. Manure was applied below the soil surface during the undercutting process; otherwise, manure was surface applied. In the roll-down system, the rye crop was flattened with a heavy roller after manure application. Rainfall was simulated within 48 h of manure application to produce runoff events. Grab samples of runoff were collected and composited for analysis. Soil samples were collected prior to treatments in the fall and spring. The roll-down system had no significant effect on water quality (sediment, nutrients, bacteria) as compared to the traditional system. While the roll-down system may require an occasional tillage operation to prevent surface compaction, it is recommended in situations where reduction of residual herbicide applications is a primary concern. The undercut system displayed evidence of a compaction layer developing below the disturbed soil layer. The undercut system reduced loadings of all nutrients, but increased losses of total suspended solids, as compared with all other systems. Mean volume of runoff from the undercut system was less than half that from any other system. Overall, the undercut system is recommended over the other systems analyzed for preventing transport of manure constituents to surface water, but should be evaluated in a complete dairy system before it is implemented by producers.
\end{abstract}

Keywords. Animal wastes, Application to land, Cover crop, Crop management, Dairy manure, Manure application, Nutrients, Roll-down, Undercut.

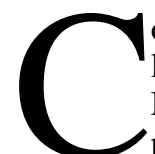

onfined livestock production systems produce large quantities of manure that must be managed. Management of livestock manures presents an important challenge to producers addressing the sometimes conflicting goals of crop production, manure utilization, and water quality protection. Potential contaminants to surface water resulting from manure applications to the land include nutrients, organic matter, and bacteria. Nutrients contribute to reported water quality problems in $50 \%$ of impaired lake hectares and in $20 \%$ of impaired river and stream kilometers, while bacteria (pathogens) contribute to problems in $39 \%$ of impaired river and stream kilometers in the U.S. (USEPA, 2002). Agriculture is the leading source of pollution in assessed rivers and streams, cited with respect to $48 \%$ of impaired river and stream kilometers and $41 \%$ of impaired lake hectares (USEPA, 2002). Producers in the U.S. face increasing pressure from state and federal regulatory agencies, as well as the public at large, to manage manure production and utilization in such a way that the environment is protected (Perkinson, 1994; Weinberg, 1994; Safley, 1994).

Article was submitted for review in August 2004; approved for publication by the Soil \& Water Division of ASAE in June 2005.

The authors are James D. Kern, Environmental Scientist, MapTech, Inc., Blacksburg, Virginia; and Mary Leigh Wolfe, ASAE Member Engineer, Associate Professor, Department of Biological Systems Engineering, Virginia Tech, Blacksburg, Virginia. Corresponding author: Mary Leigh Wolfe, Department of Biological Systems Engineering (0303), Virginia Tech, Blacksburg, VA 24061; phone: 540-231-6092; fax: 540231-3199; e-mail: mlwolfe@vt.edu.
Dairy production accounts for a significant portion of confined livestock production in the U.S. with about 9.1 million milk cows in 2003 (USDA-NASS, 2004). Assuming average daily manure production of $55 \mathrm{~kg} / \mathrm{head}$-day ( $A S A E$ Standards, 2003), approximately 183 billion $\mathrm{kg}$ of manure were produced in 2003, more than twice the amount of milk produced in the same year (77 billion $\mathrm{kg}$; USDA-NASS, 2004). In Virginia in 2003, approximately 113,000 milk cows produced about 785 million $\mathrm{kg}$ of milk (USDA-NASS, 2004) and an estimated 2 billion $\mathrm{kg}$ of manure.

Typical dairy production systems in Virginia include corn silage production, often with a rye cover crop. The traditional management system involves spraying the rye with a herbicide and planting corn into the dead crop, leaving the standing, dead crop as cover during the early stages of corn growth. A second conventional management system, commonly referred to as a double-crop system, includes harvesting the rye as forage and planting corn into the remaining stubble. This practice is commonly used where the growing season is long enough to make harvesting two crops a viable option. A herbicide is applied after harvest to kill any existing weeds and prevent regrowth of the rye crop. In both systems, manure is surface applied in the spring and fall. Surface-applied manure is readily available for transport in runoff water, particularly in cases where there is not much residue on the soil surface.

Much of this corn silage production uses conservation tillage; about $46 \%$ of the tilled land in Virginia was in conservation tillage in 1998 (Virginia Farm Bureau Federation, 1999). Walter et al. (1987) observed that there are apparently conflicting objectives between the use of conservation tillage and land application of manure, since the 
goal of conservation tillage is to maintain crop residues on the soil surface while a common recommendation for land application of manure is incorporation. Walter et al. (1987) found that a small amount of incorporation $(3 \mathrm{~cm})$ reduced phosphorus (P) losses in surface runoff to $20 \%$ of that lost with no incorporation.

Ross et al. (1979) compared water quality effects of surface application and injection of liquid dairy manure on bare and sodded plots. The percentage of applied nitrogen $(\mathrm{N})$, chemical oxygen demand (COD), and total solids (TS) measured in runoff was exponentially related to the amount of runoff. Since runoff volumes from bare soils are characteristically greater than those from soils with surface residue, one can infer that total losses of manure constituents from bare soils are higher than losses from soils with surface residue, all other factors being equal. Ross et al. (1979) also found that, under the conditions studied, injection effectively eliminated loss of manure constituents in runoff. Runoff from plots where manure was injected was compared with runoff from control plots where the injector was run through the plots without application of manure. Nearly the same quantities of COD, N, TS, total suspended solids (TSS), $\mathrm{pH}$, dissolved oxygen (DO), and fecal coliform (FC) were measured in the injection and control plots. Plots receiving the injection treatment produced no runoff in the second two years of the study due to ponding on the uphill side of ridges formed by the injection equipment.

Equipment is needed to incorporate manure in the soil uniformly, with minimal increase in power requirements and compaction (Sutton et al., 1990). The substantial power requirement of pulling manure injector shanks through the soil can be reduced dramatically by decreasing the depth of cut and increasing the width of soil disturbance (Negi et al., 1978; Godwin et al., 1985). However, the width of sweeptype injectors has been limited in the past (less than $30 \mathrm{~cm}$ wide) to allow for manure application in row crops. Laguë (1991) demonstrated that energy required for pumping manure into the ground could be avoided through the use of a gravity feed system, as long as the manure flow rate is controlled and the volume of pore space created by the injector is adequate to accommodate the injected manure.

Two innovative management techniques that may overcome disadvantages of the two conventional systems for corn silage/rye cover crop production are roll-down and undercut. The roll-down treatment incorporates the use of a heavy roller to mechanically kill the rye cover crop prior to planting corn. With proper timing, the roll-down operation breaks the stems of the rye plants and effectively kills the crop, leaving a thick matte of biomass that acts as a mulch, deterring weed growth during the corn growing season (Vaughan et al., 1992; Luna et al., 1991, 1994). A herbicide application may be necessary if the crop is at a growth stage where the stems are still resilient when the roll-down operation is completed. However, residual herbicide use can be reduced or eliminated. No studies have been performed to examine the hydrologic or water quality impacts that the roll-down technique may produce.

A second innovative treatment, undercutting, was adapted from stubble mulch farming, which has been used for the prevention of wind erosion for over 40 years in the Great Plains states (Fenster, 1960; Woodruff et al., 1965a, 1965b). Stubble mulch farming is any system for managing wheatfallow lands that maintains residue on the soil surface. A subsurface tiller can be used to kill any growing plants prior to wheat planting. The tillage implement that has evolved over the years as the best subsurface tiller is the wide V-sweep, which has been marketed in the U.S. and Canada (e.g., Lipsy, 1995). Colvin et al. (1980) reported that one pass with a V-sweep (over $0.76 \mathrm{~m}$ wide) left $90 \%$ of the surface residue undisturbed. Dickey et al. (1983) compared stubble mulch tillage to no-till and moldboard plowing with respect to soil erosion on $2.4 \times 10.7 \mathrm{~m}$ plots with a $4 \%$ slope. The stubble mulch treatment received one pass with $1.8 \mathrm{~m}$ V-blades having a $75^{\circ}$ angle, at a depth of 10 to $15 \mathrm{~cm}$. Using a rainfall simulator to mimic typical Great Plains rainfall during wheat production, Dickey et al. (1983) found no differences in the amount of soil lost from plots receiving the no-till and stubble mulch treatments. Applying manure with a gravity feed system behind a V-sweep could result in less surface disturbance than other injectors, lower energy requirements, and reduced impacts on runoff water quality.

While the innovative techniques seem to have promise, impacts on soil properties and runoff water quality, as well as crop yield and economic viability, have not been studied. The overall goal of this study was to determine if alternative management techniques, i.e., roll-down and undercut, provide environmental benefits compared to traditional and double-crop systems. The four management systems evaluated were distinguished by the methods used to manage the rye cover crop and to apply liquid dairy manure. The specific objectives were: (1) to measure the effects of the four management systems on the soil resource, including $\mathrm{P}$ and organic matter (OM) stratification, saturated hydraulic conductivity $\left(\mathrm{K}_{\mathrm{S}}\right)$, and bulk density (BD), and (2) to measure the effects of the four management systems on runoff water quantity and quality.

\section{Materials AND Methods}

A field study was conducted from March 1995 through May 1997 focusing on the four management treatments: traditional, double-crop, roll-down, and undercut. Sixteen field plots, each $4.6 \mathrm{~m}$ wide and $18.3 \mathrm{~m}$ long, were established on a $7 \%$ to $10 \%$ slope located at the Virginia Tech Kentland Research Farm in southwest Virginia. The soil is classified as a Unison and Bradock association (clayey, mixed, mesic typic hapudults; USDA-SCS, 1985). Sheet metal borders were installed around each plot to prevent runoff from entering or leaving the plot. Each plot was instrumented with a $15 \mathrm{~cm}$ standard $\mathrm{H}$-flume and a stage recorder. The plots were divided into two blocks of eight plots each. Two replications of each treatment were randomly assigned to the eight plots in each block, resulting in a generalized randomized block statistical design (fig. 1).

Experimental field operations duplicated actual field operations as closely as possible. Field operations were performed up and down the slope. The small size of the plots and the need for the sheet metal borders to remain in place necessitated performing some operations by hand, as described in the following paragraphs.

Rye (Secale cereale) was planted at a rate of $112 \mathrm{~kg} / \mathrm{ha}$ with a no-till seed drill up and down the slope. After emergence, bare areas were planted by hand. Bare areas were predominantly due to difficulty in operating the seed drill close to the sheet metal borders and comprised approximate- 

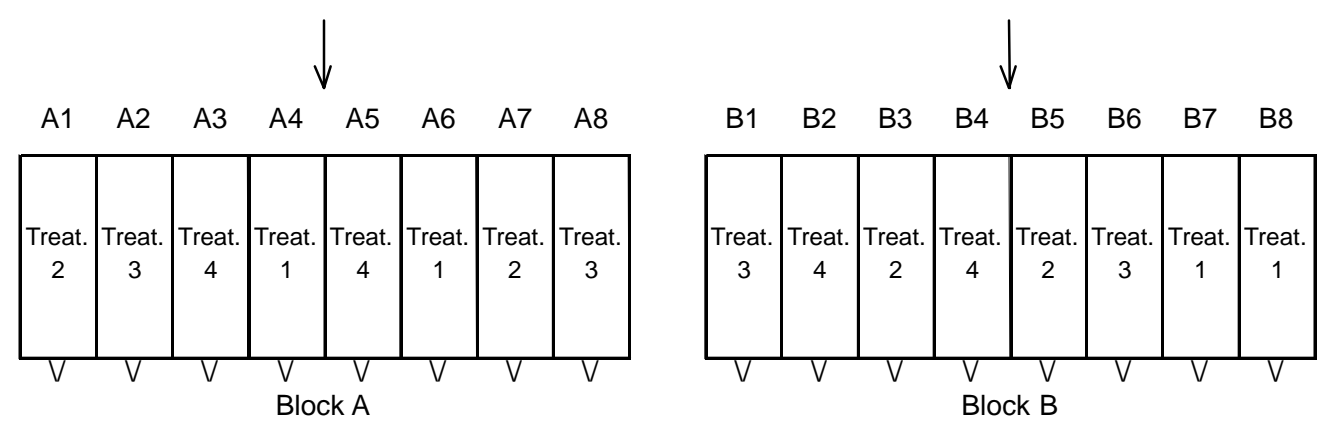

Treatment Descriptions

Treatment 1: Traditional.

Rye crop killed with herbicide. Surface application of manure.

Treatment 2: Double-crop.

Treatment 3: Roll-down.

Rye crop harvested. Surface application of manure.

Treatment 4: Undercut.

Rye crop killed with heavy roller after surface application of manure.

Rye crop killed with herbicide. Manure applied using undercutter.

Figure 1. Plot layout and experimental design.

ly $5 \%$ to $10 \%$ of the plot area. Corn (Zea mays) was planted across the slope using hand planters. Row spacing was $76.2 \mathrm{~cm}$. Plant spacing was $15.2 \mathrm{~cm}$. After emergence, the crop was thinned to a population of 59,000 plants/ha.

Crop nutrient requirements were calculated based on the recommendations of the Virginia Department of Conservation and Recreation (VADCR, 1993). Manure application rates that were calculated based on $\mathrm{N}$ requirements were large enough to supply all of the required $\mathrm{P}$ and potassium (K). In all four systems, liquid dairy manure was applied twice per year: in the spring before planting corn, and in the fall before planting rye. Average manure nutrient values, recorded at the site where manure was acquired, were used to determine application rates (table 1). A problem with manure storage at the plot site made it necessary to reduce the amount of manure applied prior to the first growing season of corn. Consequently, a supplemental application of $\mathrm{N}, \mathrm{P}$, and $\mathrm{K}$ was made approximately 15 days after emergence of the corn crop. The plots to which manure had been surface-applied received $131 \mathrm{~kg} \mathrm{~N} / \mathrm{ha}, 29 \mathrm{~kg} \mathrm{P}_{2} \mathrm{O}_{5} / \mathrm{ha}$, and $124 \mathrm{~kg} \mathrm{~K} 2 \mathrm{O} / \mathrm{ha}$. The plots to which manure had been subsurface-applied received $96 \mathrm{~kg} \mathrm{~N} / \mathrm{ha}, 29 \mathrm{~kg} \mathrm{P}_{2} \mathrm{O}_{5} / \mathrm{ha}$, and $124 \mathrm{~kg} \mathrm{~K} 2 \mathrm{O} / \mathrm{ha}$. The fertilizer was mixed from urea (46-0-0), ammonium phosphate (18-46-0), and potassium chloride (0-0-62). The amount of the mixture required for $5 \mathrm{~m}$ of row was measured out and surface-applied by hand as a sidedress. Additional manure storage facilities were acquired later that season, and all remaining manure applications were calculated to supply the total nutrient requirement of each crop.

Manure applied in the spring to the roll-down treatment was applied prior to the roll-down operation. For the undercut treatments, a $1.5 \mathrm{~m}$ wide V-sweep, supplied by New Noble Corporation, was modified so that manure could be applied behind the sweep as it cut through the soil. A manure distribution nozzle and soil deflectors were attached to the sweep (fig. 2). Manure was supplied through a gravity feed

Table 1. Liquid dairy manure application rates, nutrient fractions, and moisture content.

\begin{tabular}{|c|c|c|c|c|c|c|}
\hline \multirow[b]{2}{*}{ Crop, Year } & \multicolumn{2}{|c|}{ Application Rate (L/ha) } & \multicolumn{3}{|c|}{ Nutrient Content (kg/1000 L) } & \multirow{2}{*}{$\begin{array}{l}\text { Moisture Content } \\
(\%)\end{array}$} \\
\hline & Surface & Undercut & TKN & $\mathrm{NH}_{4}-\mathrm{N}$ & $\mathrm{TP}$ & \\
\hline Corn, 1995 & 41,200 & 41,200 & 2.39 & 0.67 & 1.49 & 93.6 \\
\hline Rye, 1995-96 & 78,600 & 53,300 & 2.48 & 0.79 & 2.26 & 90.4 \\
\hline Corn, 1996 & 136,600 & 86,000 & 3.57 & 1.18 & 1.94 & 87.4 \\
\hline Rye, 1996-97 & 60,800 & 52,400 & 3.29 & 0.87 & 2.04 & 88.9 \\
\hline Corn, 1997 & 144,000 & 96,300 & 1.88 & 0.70 & 1.53 & 93.4 \\
\hline
\end{tabular}
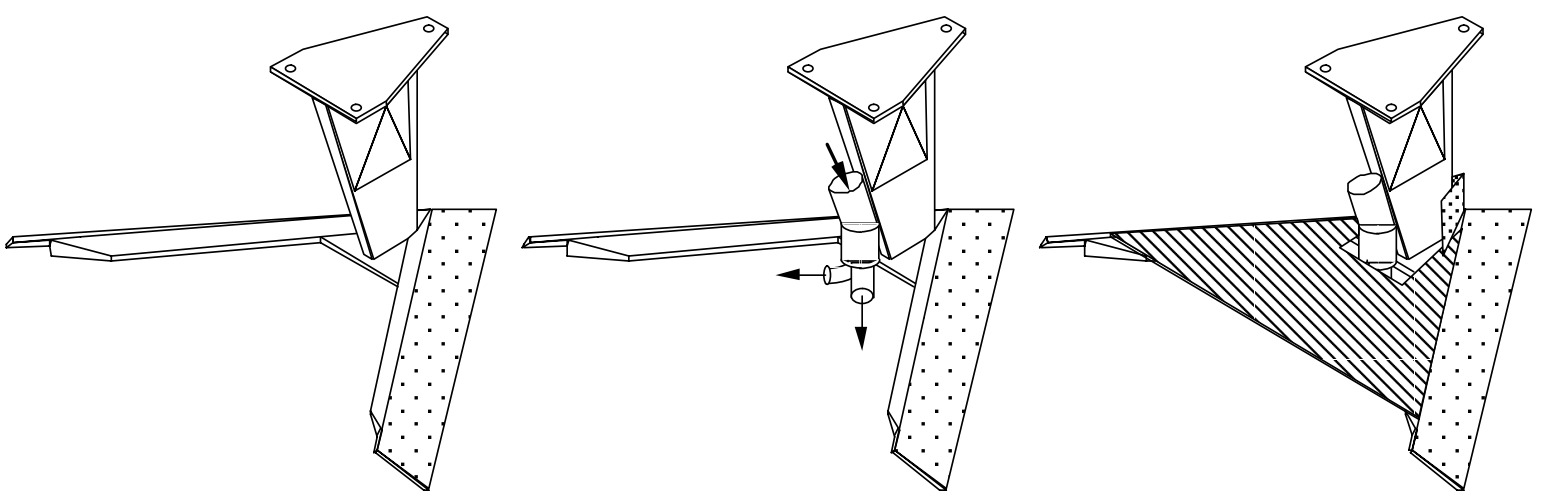

Figure 2. V-sweeps used in field study: (a) unmodified V-sweep, (b) V-sweep with manure distribution nozzle attached, and (c) V-sweep with manure distribution nozzle and soil deflectors attached. 


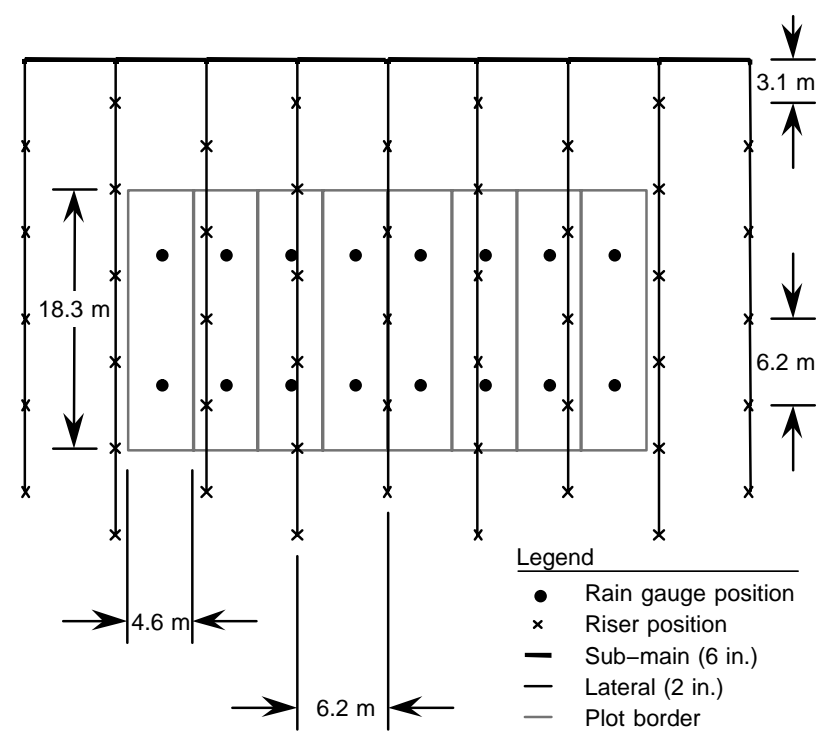

Figure 3. Rainfall simulator layout.

system, from a $568 \mathrm{~L}$ tank, through a $10 \mathrm{~cm}$ diameter pipe, to the nozzle that distributed manure behind the blade of the V-sweep. Soil deflectors were designed to protect the nozzle and keep soil from falling back into place until the manure had been distributed. Flow rate was controlled by a ball valve situated between the tank and the distribution nozzle. A constant application rate was maintained by a constant head tube located in the manure tank.

Simulated rainfall was applied to the plots twice per year within $48 \mathrm{~h}$ after each manure application. The rainfall simulator (fig. 3), described by Dillaha et al. (1987), is an irrigation system modified to apply large water droplets at a rate of approximately $50 \mathrm{~mm} / \mathrm{h}$ to simulate an intense precipitation event. The rainfall application rate of $50 \mathrm{~mm} / \mathrm{h}$ represents a 2- to 5-year return period storm for southwest Virginia (Hershfield, 1961). A sequence of three rainfall events was applied to represent three soil moisture conditions: (1) dry run, $1 \mathrm{~h}$ duration; (2) wet run, $24 \mathrm{~h}$ after the dry run, 30 min duration; and (3) very wet run, 30 min after the wet run, 30 min duration.

Soil cores $(5 \mathrm{~cm}$ diameter) were collected twice per year prior to manure application and analyzed to determine BD and $\mathrm{K}_{\mathrm{s}}$. Samples were taken at two depths $(2.5$ to $7.6 \mathrm{~cm}$ and 12.7 to $17.8 \mathrm{~cm}$ ) and in two locations in each plot. For determination of $\mathrm{BD}$ and $\mathrm{K}_{\mathrm{s}}$, the cores were first saturated from the bottom of the soil core over a $24 \mathrm{~h}$ period. A constant head apparatus (Klute and Dirksen, 1986) was used to measure $K_{s}$. Briefly, samples of water passing through the soil core were collected, and $\mathrm{K}_{\mathrm{s}}$ was calculated for each soil sample as a function of the volume of water collected, the length of the soil sample, the sampling period, the cross-sectional area of the soil sample, and the hydraulic head. After $\mathrm{K}_{\mathrm{s}}$ was measured, the soil samples were dried at $105^{\circ} \mathrm{C}$ until constant weight was achieved (Blake and Hartge, 1986).

Table 2. Natural and simulated rainfall for selected dates $(\mathrm{mm})$, averaged over all plots within a block. Uniformity coefficients (UC) reported for simulated events.

\begin{tabular}{|c|c|c|c|c|c|c|c|c|c|}
\hline \multirow[b]{2}{*}{ Season } & \multirow[b]{2}{*}{$\begin{array}{l}\text { Rainfall } \\
\text { Source }\end{array}$} & \multicolumn{4}{|c|}{ Block A } & \multicolumn{4}{|c|}{ Block B } \\
\hline & & $\begin{array}{c}\text { Julian } \\
\text { Date }\end{array}$ & Run & $\begin{array}{c}\text { Rainfall } \\
(\mathrm{mm})\end{array}$ & $\begin{array}{l}\mathrm{UC} \\
(\%)\end{array}$ & $\begin{array}{c}\text { Julian } \\
\text { Date }\end{array}$ & Run & $\begin{array}{l}\text { Rainfall } \\
(\mathrm{mm})\end{array}$ & $\begin{array}{l}\mathrm{UC} \\
(\%)\end{array}$ \\
\hline \multirow[t]{7}{*}{ Fall 1995} & Natural & 287 & & 0.0 & & 283 & & 0.0 & \\
\hline & Natural & 288 & & 0.0 & & 284 & & 0.0 & \\
\hline & Natural & 289 & & 0.0 & & 285 & & 0.0 & \\
\hline & Natural & 290 & & 0.0 & & 286 & & 0.0 & \\
\hline & Simulated & 291 & 1 & 49.1 & 92 & 287 & 1 & 49.3 & 89 \\
\hline & Simulated & 292 & 2 & 26.0 & 92 & 288 & 2 & 22.9 & 92 \\
\hline & Simulated & 292 & 3 & 25.5 & 93 & 288 & 3 & 18.0 & 91 \\
\hline \multirow[t]{7}{*}{ Spring 1996} & Natural & 134 & & 0.0 & & 130 & & 5.0 & \\
\hline & Natural & 135 & & 0.0 & & 131 & & 0.0 & \\
\hline & Natural & 136 & & 1.3 & & 132 & & 0.0 & \\
\hline & Natural & 137 & & 47.8 & & 133 & & 2.5 & \\
\hline & Simulated & 138 & 1 & 45.0 & 93 & 134 & 1 & 37.5 & 93 \\
\hline & Simulated & 139 & 2 & 21.1 & 91 & 135 & 2 & 20.3 & 91 \\
\hline & Simulated & 139 & 3 & 22.9 & 93 & 135 & 3 & 21.5 & 91 \\
\hline \multirow[t]{7}{*}{ Fall 1996} & Natural & 313 & & 20.6 & & 301 & & 4.1 & \\
\hline & Natural & 314 & & 24.1 & & 302 & & 0.0 & \\
\hline & Natural & 315 & & 0.1 & & 303 & & 0.3 & \\
\hline & Natural & 316 & & 0.1 & & 304 & & 0.5 & \\
\hline & Simulated & 317 & 1 & 38.2 & 90 & 305 & 1 & 34.9 & 91 \\
\hline & Simulated & 318 & 2 & 21.4 & 91 & 306 & 2 & 20.6 & 92 \\
\hline & Simulated & 318 & 3 & 20.2 & 83 & 306 & 3 & 21.0 & 92 \\
\hline \multirow[t]{7}{*}{ Spring 1997} & Natural & 134 & & 0.0 & & 130 & & 2.8 & \\
\hline & Natural & 135 & & 0.0 & & 131 & & 0.0 & \\
\hline & Natural & 136 & & 1.3 & & 132 & & 0.0 & \\
\hline & Natural & 137 & & 0.0 & & 133 & & 0.8 & \\
\hline & Simulated & 138 & 1 & 39.8 & 92 & 134 & 1 & 42.9 & 91 \\
\hline & Simulated & 139 & 2 & 20.3 & 93 & 135 & 2 & 20.0 & 93 \\
\hline & Simulated & 139 & 3 & 19.7 & 93 & 135 & 3 & 19.8 & 92 \\
\hline
\end{tabular}


Bulk density was calculated as the dry weight of the sample divided by the volume of the soil core. Measurements taken at a given depth in a given plot were averaged, yielding one measurement per depth per plot.

Soil samples ( $2 \mathrm{~cm}$ diameter) were taken at three depths (0 to $3.0 \mathrm{~cm}, 12.7$ to $17.8 \mathrm{~cm}$, and 27.9 to $33.0 \mathrm{~cm}$ ) to determine $\mathrm{P}$ and $\mathrm{OM}$ content prior to each manure application. The samples were analyzed for $\mathrm{P}$ and $\mathrm{OM}$ at the Virginia Tech Soil Testing and Plant Analysis Laboratory using procedures described by Donohue and Heckendorn (1994). Details of soil sampling procedures and analyses were described by Kern (1997).

Simulated rainfall amounts (table 2) were measured using rain gauges placed in the experimental plots (fig. 3). Limitations of the water supply at the field site allowed for rainfall simulation on only one block each day. The resulting rainfall simulation schedule resulted in a temporal difference between the two blocks. Stage recorders measured no runoff from the plots during natural rainfall events that occurred prior to simulation runs (table 2). The Christiansen uniformity coefficient (UC) was calculated for each simulated event (Pair et al., 1983).

Grab samples of runoff were taken during the simulated rainfall events at 6 min intervals. One sample was composited for each plot using a backward flow weighting scheme. Specifically, the volume of each sample mixed in the composite was proportional to the volume of runoff measured between its collection time and the previous sample's collection time. Composite runoff samples were analyzed in the Water Quality Laboratory in the Department of Biological Systems Engineering at Virginia Tech using colorimetric methods on a TRAACS 800 (Bran + Luebbe, Inc., Buffalo Grove, Ill.). The following constituents were measured (method numbers are indicated in parentheses): TSS (160.2; USEPA, 1983), total Kjeldahl N (TKN) (351.2; USEPA, 1983), dissolved TKN (DTKN) (351.2; USEPA, 1983), ammonium $\mathrm{N}\left(\mathrm{NH}_{4}-\mathrm{N}\right)$ (350.1; USEPA, 1983), nitrate $\mathrm{N}$ $\left(\mathrm{NO}_{3}-\mathrm{N}\right)$ (353.1; USEPA, 1983), total P (TP) (365.4; USEPA, 1983), dissolved TP (DTP) (365.4; USEPA, 1983), orthophosphate $\mathrm{P}\left(\mathrm{PO}_{4}-\mathrm{P}\right)$ (365.1; USEPA, 1983), total coliform bacteria (TC) (909A; Greenberg et al., 1985), FC bacteria (909C; Greenberg et al., 1985), and Escherichia coli bacteria (EC) (909A; Greenberg et al., 1985).

Concentration measurements acquired from a given plot in a given season were averaged over the three runs measured during that season. Averages were weighted based on the measured volume of runoff from each run. Pollutant loadings were calculated for each plot in each season by multiplying the concentration measured in a given run by the volume of runoff measured from that run, and summing over the three runs made during the season.

A general linear model (GLM) was used to analyze all data. All data were treated as normally distributed, except for $\mathrm{K}_{\mathrm{s}}$ and bacterial water quality data, which were treated as log-normally distributed, and geometric means are reported in this analysis. Factors considered in the statistical model included year, season, block, depth (soil analyses only), and treatment. The procedure outlined by Milliken and Johnson (1992) for analyzing three-way and higher-order treatment structures was used in each analysis. The process resulted in one or more data sets, determined based on the significance of treatment interactions. Fisher's least significant difference (LSD) procedure (Milliken and Johnson, 1992) was used to compare treatment means where treatment effects were significant at the alpha $=0.05$ level. All analyses were performed using JMP IN statistical software (Sall and Lehman, 1996).

\section{Results AND Discussion}

\section{SoIL ANALYSES}

Initial measurements of soil $\mathrm{P}, \mathrm{OM}, \mathrm{BD}$, and $\mathrm{K}_{\mathrm{s}}$ showed no differences among treatments. Average initial values were $5.98 \mathrm{ppm}, 2.12 \%, 1.40 \mathrm{~g} / \mathrm{cm}^{3}$, and $1.81 \mathrm{~cm} / \mathrm{h}$, respectively, averaged across measurement depths. Final average levels of $\mathrm{P}$ and $\mathrm{OM}$ were $8.95 \mathrm{ppm}$ and $2.39 \%$, respectively. The Mehlich-1 extractant method (Mehlich, 1953) was used to measure soil test P. Much of the P applied in manure is in organic forms, which are not measured by the Mehlich-1 method. The changes in OM content and in the $\mathrm{P}$ forms measured were small compared with the variability of the measurements, and no significant differences were measured.

Results of the $\mathrm{BD}$ and $\mathrm{K}_{\mathrm{s}}$ analyses conducted at the conclusion of the experiment indicated compaction at the 2.5 to $7.6 \mathrm{~cm}$ depth in the undercut plots (table 3). Because the soil samples were collected prior to treatment operations, approximately six months after the previous undercutting operation, growing season effects on $\mathrm{BD}$ and $\mathrm{K}_{\mathrm{s}}$ are seen in these results. It is likely that the disturbed layer of soil $(0$ to $15 \mathrm{~cm})$ in the undercut system was compacted by traffic on the plots, which was necessary for planting and herbicide applications. Because this layer of soil is loosened by the undercutter during each undercutting operation and compaction had no effect on yield (Kern, 1997), there should be no long-term compaction problem at this depth. Compaction was also evident at the 15.2 to 20.3 $\mathrm{cm}$ depth in the undercut plots (table 3 ). This may indicate a more important problem than compaction at the shallower depth, since soil at this depth is not regularly loosened. The increase in BD may indicate the development of a plowpan just below the depth where the undercutter was run. The measured decrease in $\mathrm{K}_{\mathrm{s}}$ for the double-crop plots indicated a slight degree of compaction at the 2.5 to $7.6 \mathrm{~cm}$ depth (table 3 ). Traffic in the double-crop plots may have led to compaction, since the bare soil had no residue cover to provide a cushioning effect for the soil.

\begin{tabular}{|c|c|c|c|c|}
\hline \multirow[b]{2}{*}{ Treatment } & \multicolumn{2}{|c|}{ BD } & \multicolumn{2}{|l|}{$\overline{\mathrm{K}_{\mathrm{s}}}$} \\
\hline & $\begin{array}{c}\text { Mean } \\
\left(\mathrm{g} / \mathrm{cm}^{3}\right)\end{array}$ & $\begin{array}{l}\text { Std } \\
\text { Dev. }\end{array}$ & $\begin{array}{c}\text { Geometric } \\
\text { Mean }(\mathrm{cm} / \mathrm{h})\end{array}$ & $\begin{array}{l}\text { Std } \\
\text { Dev. }\end{array}$ \\
\hline \multicolumn{5}{|l|}{2.5 to $7.6 \mathrm{~cm}$ depth } \\
\hline Double-crop & $1.29 \mathrm{a}$ & 0.040 & $1.73 \mathrm{a}, \mathrm{b}$ & 0.542 \\
\hline Roll-down & $1.23 \mathrm{a}$ & 0.062 & $5.36 \mathrm{~b}, \mathrm{c}$ & 1.203 \\
\hline Traditional & $1.27 \mathrm{a}$ & 0.053 & $6.82 \mathrm{c}$ & 0.674 \\
\hline Undercut & $1.44 \mathrm{~b}$ & 0.082 & $0.59 \mathrm{a}$ & 0.518 \\
\hline \multicolumn{5}{|c|}{15.2 to $20.3 \mathrm{~cm}$ depth } \\
\hline Double-crop & $1.49 \mathrm{a}, \mathrm{b}$ & 0.036 & $0.77 \mathrm{a}$ & 0.410 \\
\hline Roll-down & $1.49 \mathrm{a}, \mathrm{b}$ & 0.032 & $3.21 \mathrm{a}$ & 0.901 \\
\hline Traditional & $1.45 \mathrm{a}$ & 0.073 & $0.71 \mathrm{a}$ & 0.343 \\
\hline Undercut & $1.55 \mathrm{~b}$ & 0.059 & $1.03 \mathrm{a}$ & 1.809 \\
\hline
\end{tabular}

[a] Treatment means followed by the same letter are not significantly different from each other at the $\alpha=0.05$ level. 


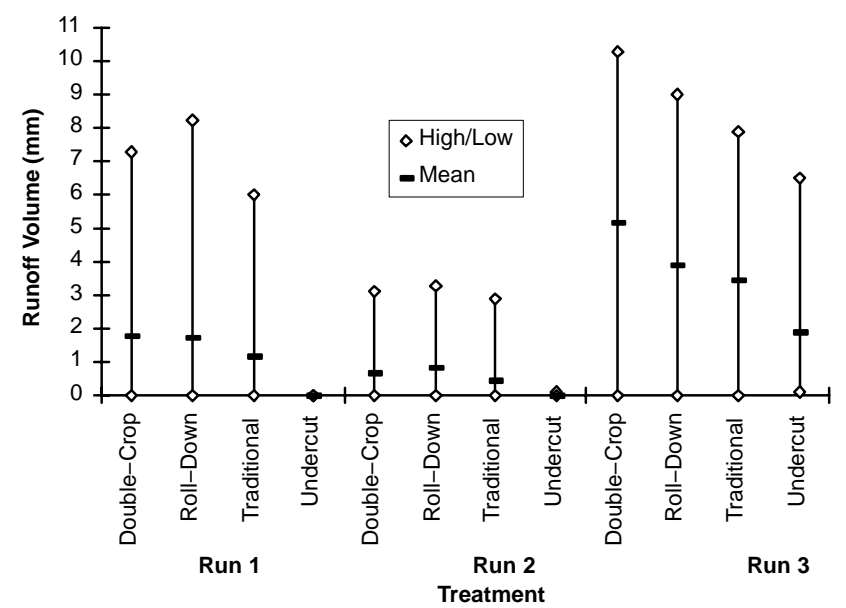

Figure 4. Measured runoff volume by run and treatment for simulated rainfall events 1995-1997 (run $1=60 \mathrm{~min}$ duration; run $2=24 \mathrm{~h}$ after run 1, 30 min duration; and run $3=30 \mathrm{~min}$ after run $2,30 \mathrm{~min}$ duration).

\section{RUNOFF QUANTITY}

Effects of rainfall event duration and antecedent soil moisture content were seen in the measured runoff (fig. 4). The mean volume of runoff from undercut plots was less than half that from any other treatment. This difference is likely due to higher rainfall storage capacity in the undercut plots. The combination of a standing crop and a roughened soil surface provided storage that was unavailable in the doublecrop and roll-down plots. The undercutting process breaks up any surface crusting and may consequently increase infiltration rates in the short term.

\section{RuNOFF QUALITY \\ Total Suspended Solids}

Mean TSS concentration from the undercut plots was significantly greater than from all other plots, probably due to the soil disturbance discussed earlier. In the undercut plots, concentrations were highest during run 3 (fig. 5). It is possible that surface depressions began to over-top during run 3, increasing runoff volumes, runoff velocities, and transport capacity of the runoff.

Mean TSS concentration from the double-crop treatment was almost two times greater than that of the traditional and roll-down treatments, though no significant difference was determined at the alpha $=0.05$ level. This higher TSS concentration was probably due to the lack of cover after the rye crop was harvested. The decrease in mean TSS concentration in runs 2 and 3 , as compared with the mean concentration during run 1, may indicate a "first-flush" effect. This situation would imply that a substantial portion of the solids leaving the double-crop system was comprised of manure constituents. After the most mobile elements of the

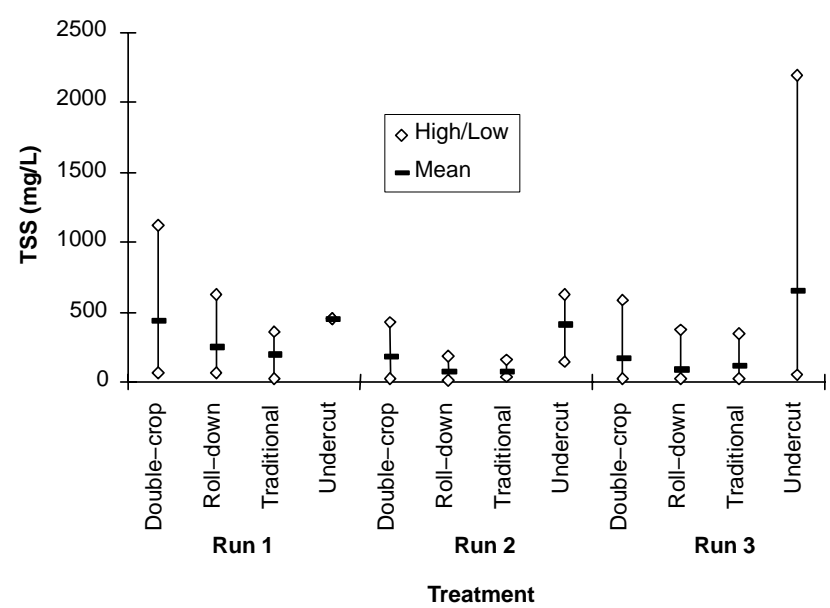

Figure 5. Total suspended solids concentration by run and treatment for simulated rainfall events 1995-1997 (run $1=60 \mathrm{~min}$ duration; run $2=24 \mathrm{~h}$ after run $1,30 \mathrm{~min}$ duration; and run $3=30 \mathrm{~min}$ after run $2,30 \mathrm{~min}$ duration).

manure were washed away in the first event, less were available for transport during the following events.

There were no statistically significant treatment effects on TSS loading (table 4). While TSS concentrations were significantly higher in runoff from undercut plots than in runoff from other plots, the loading of TSS from undercut plots was not significantly different from the loadings produced by other plots, due to the lower runoff volumes produced in the undercut plots. Mean TSS loading from undercut plots was less than mean TSS loading from double-crop plots. TSS loadings from undercut plots tended to increase with the higher runoff volumes produced by the third run of the rainfall simulator (fig. 6). Since a comparable increase was not seen in the other treatments, TSS loading from undercut plots during extreme rainfall events may increase to a level that is significantly greater than that produced in other treatments.

\section{Phosphorus Forms}

A similar pattern was observed in concentrations of all $\mathrm{P}$ forms analyzed, with comparable $\mathrm{P}$ concentrations in runoff from plots where manure was surface applied and lower $\mathrm{P}$ concentrations in runoff from undercut plots (represented by TP concentration, fig. 7). While the undercut system produced higher concentrations of TSS than the other systems, P losses were reduced by the undercut system compared to the other systems. These differences indicate that the solids lost from the systems where manure was surface applied were richer in $\mathrm{P}$ than the solids lost from the undercut system. It is likely that the solids lost from the non-undercut systems were largely composed of manure constituents, whereas the solids lost from the undercut system were largely composed of surface soil that was disturbed by the undercutter.

Table 4. Results of means comparisons of water quality constituent loading data. ${ }^{[a]}$

\begin{tabular}{|c|c|c|c|c|c|c|c|c|}
\hline Treatment & $\begin{array}{c}\text { TSS } \\
\text { (kg/ha) }\end{array}$ & $\begin{array}{c}\text { TP } \\
\text { (kg/ha) }\end{array}$ & $\begin{array}{c}\text { DTP } \\
(\mathrm{kg} / \mathrm{ha})\end{array}$ & $\begin{array}{l}\mathrm{PO}_{4}-\mathrm{P} \\
\text { (kg/ha) }\end{array}$ & $\begin{array}{c}\text { TKN } \\
(\mathrm{kg} / \mathrm{ha})\end{array}$ & $\begin{array}{l}\text { DTKN } \\
\text { (kg/ha) }\end{array}$ & $\begin{array}{l}\mathrm{NH}_{4}-\mathrm{N} \\
(\mathrm{kg} / \mathrm{ha})\end{array}$ & $\begin{array}{l}\mathrm{NO}_{3}-\mathrm{N} \\
(\mathrm{kg} / \mathrm{ha})\end{array}$ \\
\hline Double-crop & $35.48 \mathrm{a}$ & $1.55 \mathrm{~b}$ & $0.620 \mathrm{~b}$ & $0.673 \mathrm{~b}$ & $2.44 \mathrm{a}$ & $1.03 \mathrm{~b}$ & $0.557 \mathrm{~b}$ & $0.550 \mathrm{a}$ \\
\hline Roll-down & $19.27 \mathrm{a}$ & $1.10 \mathrm{a}, \mathrm{b}$ & $0.611 b$ & $0.791 \mathrm{~b}$ & $1.93 \mathrm{a}$ & $0.68 \mathrm{a}, \mathrm{b}$ & $0.399 \mathrm{a}, \mathrm{b}$ & $0.611 \mathrm{a}$ \\
\hline Traditional & $17.62 \mathrm{a}$ & $0.94 \mathrm{a}, \mathrm{b}$ & $0.500 \mathrm{~b}$ & $0.569 \mathrm{~b}$ & $1.67 \mathrm{a}$ & $0.71 \mathrm{a}, \mathrm{b}$ & $0.457 \mathrm{a}, \mathrm{b}$ & $0.375 \mathrm{a}$ \\
\hline Undercut & $31.44 \mathrm{a}$ & $0.05 \mathrm{a}$ & $0.009 \mathrm{a}$ & $0.017 \mathrm{a}$ & $0.25 \mathrm{a}$ & $0.08 \mathrm{a}$ & $0.015 \mathrm{a}$ & $0.292 \mathrm{a}$ \\
\hline
\end{tabular}

[a] Treatment means followed by the same letter are not significantly different from each other at the $\alpha=0.05$ level. 


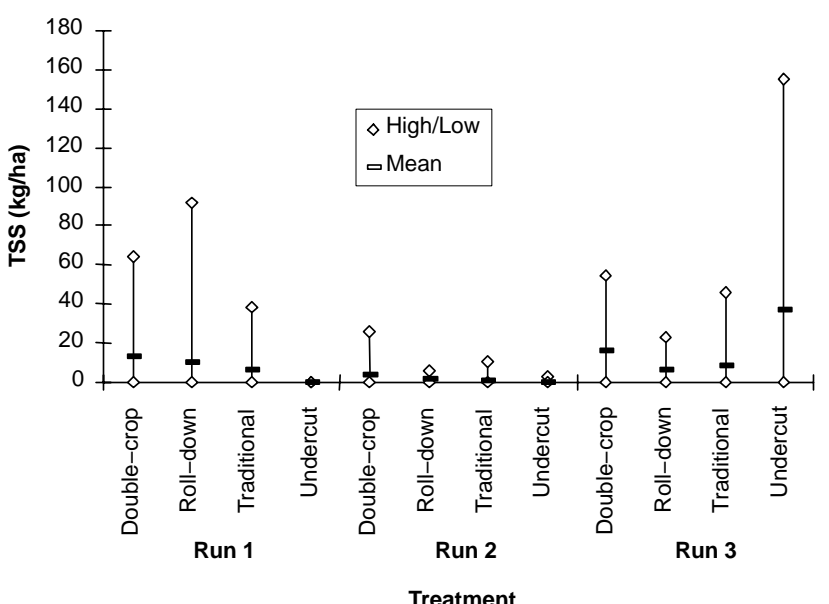

Figure 6. Total suspended solids loadings by run and treatment for simulated rainfall events 1995-1997 (run $1=60$ min duration; run $2=24 \mathrm{~h}$ after run $1,30 \mathrm{~min}$ duration; and run $3=30 \mathrm{~min}$ after run $2,30 \mathrm{~min}$ duration).

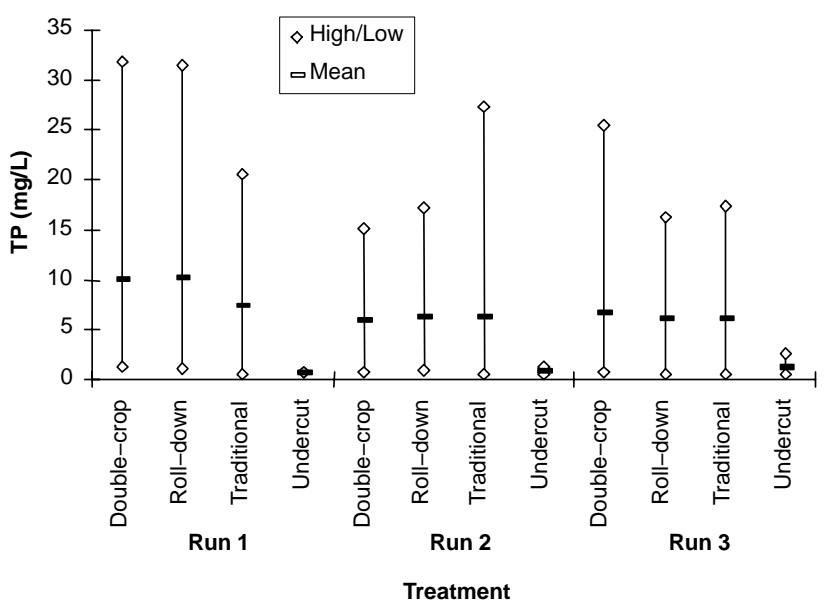

Figure 7. Total phosphorus concentration by run and treatment for simulated rainfall events 1995-1997 (run $1=60$ min duration; run $2=24 \mathrm{~h}$ after run $1,30 \mathrm{~min}$ duration; and run $3=30 \mathrm{~min}$ after run $2,30 \mathrm{~min}$ duration).

In the case of DTP and $\mathrm{PO}_{4}-\mathrm{P}$ loadings from undercut plots, lower observed runoff volumes combined with constituent concentrations to magnify treatment differences when constituent loadings were compared (table 4). In both cases, mean loadings were significantly less from undercut plots than from all other plots. Mean loadings of TP from undercut plots were significantly less than those from double-crop plots (table 4). While mean TP loadings from traditional and roll-down plots were over 18 times greater than that from undercut plots, this difference was not statistically significant, due largely to the high variability in TP loading from non-undercut plots.

\section{Nitrogen Forms}

The TKN, DTKN, and $\mathrm{NH}_{4}-\mathrm{N}$ data showed the same trends that were seen in the $\mathrm{P}$ concentration data, with comparable concentrations among non-undercut systems and decreased concentrations in runoff from the undercut system. However, differences were not as dramatic. With the exception of $\mathrm{NO}_{3}-\mathrm{N}$ concentrations, mean values of $\mathrm{N}$ concentrations were generally, if not significantly, lower in undercut plot runoff than in runoff from plots where manure

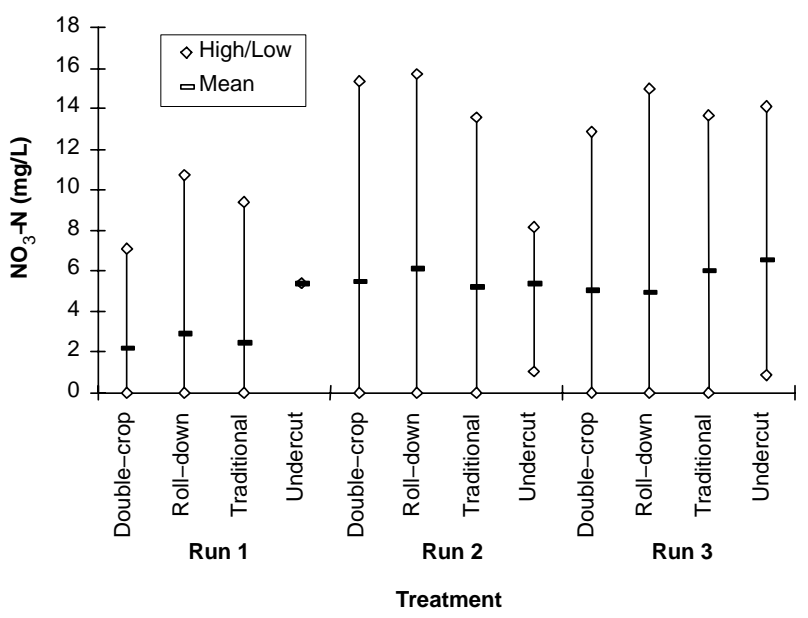

Figure 8. Nitrate nitrogen concentration by run and treatment for simulated rainfall events 1995-1997 (run $1=60$ min duration; run $2=24 \mathrm{~h}$ after run $1,30 \mathrm{~min}$ duration; and run $3=30 \mathrm{~min}$ after run $2,30 \mathrm{~min}$ duration).

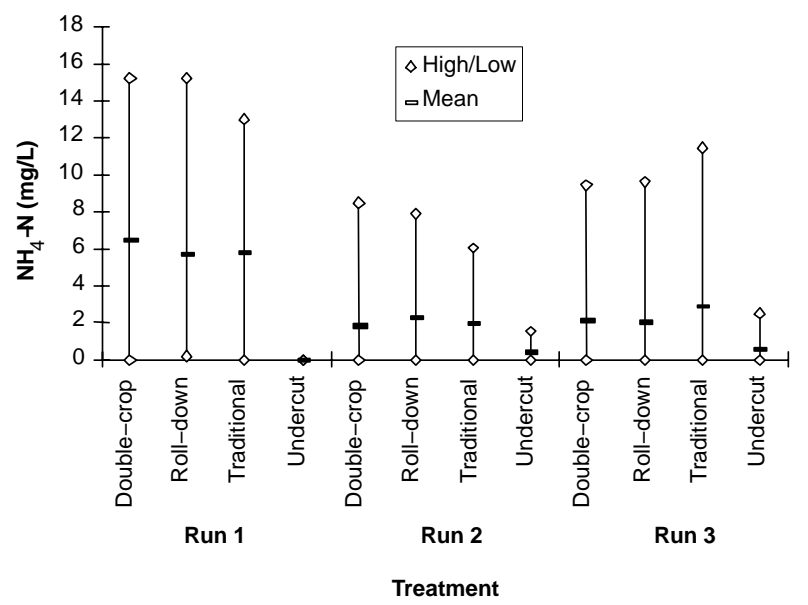

Figure 9. Ammonium nitrogen concentration by run and treatment for simulated rainfall events 1995-1997 (run $1=60 \mathrm{~min}$ duration; run $2=24 \mathrm{~h}$ after run $1,30 \mathrm{~min}$ duration; and run $3=30 \mathrm{~min}$ after run $2,30 \mathrm{~min}$ duration).

was surface applied. The increase in $\mathrm{NO}_{3}-\mathrm{N}$ concentration during the second and third run (fig. 8) might be explained by increased $\mathrm{NO}_{3}-\mathrm{N}$ in the surface layer of soil due to nitrification of $\mathrm{NH}_{4}-\mathrm{N}$. The $\mathrm{NH}_{4}-\mathrm{N}$ concentrations tended to mirror the $\mathrm{NO}_{3}-\mathrm{N}$ concentrations measured in runoff from the plots where manure was surface applied (fig. 9). Ammonium $\mathrm{N}$ concentrations dropped considerably after the first run, and $\mathrm{NO}_{3}-\mathrm{N}$ concentrations increased considerably after the first run. These changes may be evidence of nitrification occurring between the first and second run.

Mean loadings of DTKN and $\mathrm{NH}_{4}-\mathrm{N}$ from undercut plots were significantly less than those from double-crop plots (table 4). While the mean loading of $\mathrm{NO}_{3}-\mathrm{N}$ from undercut plots was less than those from plots where manure was surface applied, means comparisons (table 4) showed no significant differences.

\section{Bacteria}

No significant treatment effects on bacteria concentrations were observed (table 5). Although the mean concentrations of FC and EC were lowest in runoff from the undercut plots, high variability masked any significant differences. 
Table 5. Results of means comparisons of bacteria concentration data.[a]

\begin{tabular}{|c|c|c|c|c|c|c|}
\hline \multirow[b]{2}{*}{ Treatment } & \multicolumn{2}{|c|}{ Total Coliform } & \multicolumn{2}{|c|}{ Fecal Coliform } & \multicolumn{2}{|c|}{ E. coli } \\
\hline & $\begin{array}{l}\text { Geometric Mean } \\
(\mathrm{col} / 100 \mathrm{~mL})\end{array}$ & $\begin{array}{l}\text { Mean } \\
\ln (\mathrm{TC})\end{array}$ & $\begin{array}{l}\text { Geometric Mean } \\
(\mathrm{col} / 100 \mathrm{~mL})\end{array}$ & $\begin{array}{l}\text { Mean } \\
\ln (\mathrm{FC})\end{array}$ & $\begin{array}{l}\text { Geometric Mean } \\
(\mathrm{col} / 100 \mathrm{~mL})\end{array}$ & $\begin{array}{l}\text { Mean } \\
\ln (E C)\end{array}$ \\
\hline Double-crop & 1982759 & $14.5 \mathrm{a}$ & 6265 & $8.74 \mathrm{a}$ & 7285 & $8.89 \mathrm{a}$ \\
\hline Roll-down & 2191288 & $14.6 \mathrm{a}$ & 7933 & $8.98 \mathrm{a}$ & 13630 & $9.52 \mathrm{a}$ \\
\hline Traditional & 1329083 & $14.1 \mathrm{a}$ & 2878 & $7.97 \mathrm{a}$ & 8267 & $9.02 \mathrm{a}$ \\
\hline Undercut & 1794075 & $14.4 \mathrm{a}$ & 646 & $6.47 \mathrm{a}$ & 1640 & $7.40 \mathrm{a}$ \\
\hline
\end{tabular}

[a] Treatment means followed by the same letter are not significantly different from each other at the $\alpha=0.05$ level.

\section{Comparisons to The Traditional System}

The final $\mathrm{K}_{\mathrm{s}}$ of the double-crop system at the 2.5 to $7.6 \mathrm{~cm}$ depth was higher than that of the traditional system, possibly due to the lack of cover to act as a cushion during spring field operations. As a result, primary tillage may be required in this system earlier than in the traditional system. There was no measurable difference between the double-crop and the traditional system in terms of runoff quantity or quality. However, a standing cover crop was shown to be effective in reducing runoff volumes.

There were no measurable differences between the roll-down system and the traditional system in terms of effects on soil, runoff quantity, or runoff quality. However, the roll-down system offers the potential for reduction in herbicide applications, as stated earlier.

The undercut system showed evidence of compaction in the 2.5 to $7.6 \mathrm{~cm}$ depth range. However, any soil at this depth is loosened twice per year by the undercutting operation. The undercut system also showed signs of compaction at the 15.2 to $20.3 \mathrm{~cm}$ depth, which may indicate development of a plowpan. This system is likely to require a primary tillage operation sooner than the traditional system. Volume of runoff from the undercut system was considerably less than that from the traditional system. The undercut system was effective at placing manure constituents below the soil surface where they were less available for transport in runoff water. The undercut system reduced concentrations and loadings of all $\mathrm{P}$ forms. Concentrations and loadings of TKN, DTKN, and $\mathrm{NH}_{4}-\mathrm{N}$ tended to be less in the undercut system than in the traditional system, although the difference could not be established statistically.

The results indicate that choosing among the investigated systems depends on how the concerns of the decision maker are prioritized. If maximizing forage production is of primary interest, then the double-crop system should be implemented. If preventing transport of manure constituents to surface water is of primary concern, then the undercut system is superior to the other systems; however, the undercut system may cause soil compaction problems over time. In addition, the current sweep design disturbs the soil too much. The roll-down system is recommended if reduction of residual herbicide applications is the primary concern.

\section{Conclusion}

Four management systems were evaluated with respect to water quality and soil system impacts. The systems evaluated were distinguished by the methods used to manage the rye cover crop and to apply liquid dairy manure. The four management systems were referred to as: traditional, doublecrop, roll-down, and undercut. Two of the systems, traditional and double-crop, employed conventional practices. The roll-down and undercut systems employed innovative practices. Simulated rainfall was applied within $48 \mathrm{~h}$ of manure application each season. Soil compaction and runoff quantity and quality were analyzed.

The overall goal of this study was to determine if alternative management techniques have environmental benefits compared to the traditional and double-crop systems. The results indicated that the undercut system was better than the other systems in preventing transport of manure constituents to surface water. However, the current sweep design disturbs the soil too much, and soil compaction may be a problem. More research should be pursued to investigate alternative designs for a wide sweep injector. Specifically, a lower profile sweep with a less aggressive approach angle may produce all of the positive results of the undercutter tested in this study without the high concentrations of TSS and surface soil disturbance. Use of the undercutter along the contour should also be explored, as it may reduce concentrations of TSS considerably.

The roll-down system should be investigated further because it has the potential to reduce residual herbicide applications. Specifically, an improved manure applicator that applies the manure at the soil surface through drop tubes would result in more manure directly in contact with the soil and less on the rye plants. After the roll-down operation, less manure may be available for transport in runoff water. An improved planter that would till a narrow strip in the rolled-down material might produce yields comparable to those seen in the double-crop plots.

\section{ACKNOWLEDGEMENTS}

This work was funded by the Virginia Water Resources Research Center and the Department of Biological Systems Engineering at Virginia Tech. Appreciation is extended to Virginia Tech's Kentland Research Farm and Dairy Cattle Center, Wall Brothers' Dairy, and the Water Quality Laboratory of the Department of Biological Systems Engineering at Virginia Tech.

\section{REFERENCES}

ASAE Standards. 2003. D384.1: Manure production and characteristics. St. Joseph, Mich.: ASAE.

Blake, G. R., and K. H. Hartge. 1986. Bulk density. In Methods of Soil Analysis, Part 1: Physical and Mineralogical Methods, 363-375. 2nd ed. A. Klute, ed. Madison, Wisc.: American Society of Agronomy.

Colvin, T. S., J. M. Laflen, and D. C. Erbach. 1980. A review of residue reduction by individual tillage implements. In Crop Production with Conservation in the 80's: Proc. ASAE Conference on Crop Production with Conservation in the 80's, 102-110x. St. Joseph, Mich.: ASAE. 
Dickey, E. C., C. R. Fenster, J. M. Laflen, and R. H. Michelson. 1983. Effects of tillage on soil erosion in a wheat-fallow rotation. Trans. ASAE 26(3): 814-820.

Dillaha, T. A., B. B. Ross, S. Mostaghimi, C. D. Heatwole, V. O. Shanholtz, and F. B. Givens. 1987. Rainfall simulation/water quality monitoring for BMP effectiveness evaluation. Richmond, Va.: Virginia Division of Soil and Water Conservation.

Donohue, S. J., and S. E. Heckendorn. 1994. Laboratory procedures: Virginia Tech Soil Testing and Plant Analysis Laboratory. VCE Publication 452-881. Blacksburg, Va.: Virginia Polytechnic Institute and State University.

Fenster, C. R. 1960. Stubble mulching with various types of machinery. SSSA Proc. 24: 518-523.

Godwin, R. J., N. L. Warner, and J. E. Hall. 1985. Soil injection of liquid wastes. In Agricultural Waste Utilization and Management: Proc. 5th International Symposium on Agricultural Wastes, 63-72. St. Joseph, Mich.: ASAE.

Greenberg, A. E., R. R. Trussell, and L. S. Clesceri, eds. 1985. Standard Methods for the Examination of Water and Wastewater. 16th ed. Washington, D.C.: APHA.

Hershfield, D. N. 1961. Rainfall frequency atlas of the United States. Technical Paper 40. Washington, D.C.: U.S. Weather Bureau.

Kern, J. D. 1997. Water quality impacts of cover crop/manure management systems. PhD diss. Blacksburg, Va.: Department of Biological Systems Engineering, Virginia Polytechnic Institute and State University.

Klute, A., and C. Dirksen. 1986. Hydraulic conductivity and diffusivity: Laboratory methods. In Methods of Soil Analysis, Part 1: Physical and Mineralogical Methods, 687-734. 2nd ed. A. Klute, ed. Madison, Wisc.: American Society of Agronomy.

Laguë, C. 1991. Design of a semi-liquid dairy cattle manure spreader/injector Applied Eng. in Agric. 7(6): 655-660.

Lipsy, W. 1995. Representative of New Noble Corporation, Calgary, Alberta, Canada. Personal communication.

Luna, J. M., V. G. Allen, W. L. Daniels, J. P. Fontenot, P. G. Sullivan, C. A. Laub, N. D. Stone, D. H. Vaughan, E. S. Hagood, and D. B. Taylor. 1991. Low-input crop and livestock systems in the southeastern United States. In Sustainable Agriculture Research and Education in the Field, 183-205. Washington, D.C.: National Academy Press.

Luna, J. M., V. G. Allen, J. P. Fontenot, W. L. Daniels, D. H. Vaughan, E. S. Hagood, D. B. Taylor, and C. A. Laub. 1994. Whole farm systems research: An integrated crop and livestock systems comparison study. American J. Alternative Agric. 9(1/2): 57-63.

Milliken, G. A., and D. E. Johnson. 1992. Analysis of Messy Data. New York, N.Y.: Van Nostrand Reinhold.

Mehlich, A. 1953. Determinations of $\mathrm{P}, \mathrm{Ca}, \mathrm{Mg}, \mathrm{K}, \mathrm{Na}$, and $\mathrm{NH}_{4}$ by North Carolina soil testing laboratories. Raleigh, N.C.: North Carolina Department of Agriculture.

Negi, S. C., E. McKyes, R. J. Godwin, and J. R. Ogilvie. 1978. Design and performance of a liquid manure injector. Trans. ASAE 21(5): 963-966, 971.
Pair, C. H., W. H. Hinz, K. R. Frost, R. E. Sneed, and T. J. Schiltz. 1983. Irrigation. Arlington, Va.: The Irrigation Association.

Perkinson, R. 1994. Evolution of nutrient management in the Chesapeake Bay region. J. Soil and Water Cons. 49(2): 87-88.

Ross, T. J., S. Sizemore, J. P. Bowden, and C. T. Haan. 1979. Quality of runoff from land receiving surface application and injection of liquid dairy manure. Trans. ASAE 22(5): 1058-1062.

Safley, L. M. 1994. Best management practices for livestock production. J. Soil and Water Cons. 49(2): 57-62.

Sall, J., and A. Lehman. 1996. JMP Start Statistics: A Guide to Statistics and Data Analysis Using JMP and JMP IN Software. Belmont, Cal.: Duxbury Press.

Sutton, A. L., D. M. Huber, and D. D. Jones. 1990. Strategies for maximizing the nutrient utilization of animal wastes as a fertilizer source. In Agricultural and Food Processing Waste Management: Proc. 6th International Symposium on Agricultural Wastes, 139-147. St. Joseph, Mich.: ASAE.

USDA-NASS. 2004. Milk production. Washington, D.C.: USDA National Agricultural Statistics Service. Available at: http://usda.mannlib.cornell.edu/reports/nassr/dairy/pmp-bb/2004 /mkpr0204.pdf. Accessed 10 August 2004.

USDA-SCS. 1985. Soil survey of Montgomery County, Virginia. Washington, D.C.: USDA-SCS.

USEPA. 1983. Methods for chemical analysis of water and wastes. EPA/600/4-79/020. Washington, D.C.: U.S. EPA, Office of Research and Development.

USEPA. 2002. National water quality inventory 2000 report. Washington, D.C.: U.S. EPA, Office of Water. Available at: www.epa.gov/305b/2000report/. Accessed 17 March 2004.

VADCR. 1993. Nutrient Management Handbook. 2nd ed. Richmond, Va.: Virginia Department of Conservation and Recreation.

Vaughan, D. H., J. M. Luna, C. A. Laub, and D. R. Ess. 1992. Strip tillage in reduced chemical input corn production. ASAE Paper No. 921559. St. Joseph, Mich.: ASAE.

Virginia Farm Bureau Federation. 1999. News archives. Available at: www.vafb.comnews/1999/dec/123099_4.htm. Accessed 1 April 2004.

Walter, M. F., T. L. Richard, P. D. Robillard, and R. Muck. 1987. Manure management with conservation tillage. In Effects of Conservation Tillage on Groundwater Quality: Nitrates and Pesticides, 253-270. T. J. Logan et al., eds. Chelsea, Mich.: Lewis Publishers.

Weinberg, A. C. 1994. Coastal zone act reauthorization amendments of 1990 (CZARA). J. Soil and Water Cons. 49(2): 71-72.

Woodruff, N. P., C. R. Fenster, W. S. Chepil, and F. H. Siddoway. 1965a. Performance of tillage implements in a stubble mulch system: I. Residue conservation. Agronomy J. 57: 45-49.

Woodruff, N. P., C. R. Fenster, W. S. Chepil, and F. H. Siddoway. 1965b. Performance of tillage implements in a stubble mulch system: II. Effects on soil cloddiness. Agronomy J. 57: 49-51. 
